\title{
Haemolysin production by strains of Verocytotoxin-producing Escherichia coli
}

\author{
Henrik Chart, Claire Jenkins, Henry R. Smith, Dawn Hedges \\ and Bernard Rowe
}

Laboratory of Enteric Pathogens, Central Public Health Laboratory, 61 Colindale Avenue, London NW9 5HT, UK

\begin{abstract}
Author for correspondence: Henrik Chart. Tel: +44 181200 4400. Fax: +441819059929. e-mail: hchart@phls.co.uk
\end{abstract}

\begin{abstract}
Twenty-one strains of Verocytotoxin-producing Escherichia coli (VTEC) that hybridized with DNA probe CVD419 were examined for the ability to produce haemolysin. With solid media, all strains produced most haemolysin when grown in blood agar tubes and least when grown on blood agar plates incubated in air. Haemolysin production was increased considerably by incubating blood agar plates in an atmosphere comprising $8 \%$ carbon dioxide, $40 \%$ hydrogen and $52 \%$ nitrogen at $37{ }^{\circ} \mathrm{C}$ for $16 \mathrm{~h}$, followed by $6 \mathrm{~h}$ at $21{ }^{\circ} \mathrm{C}$ in air. Haemolysin production was also increased when strains were grown on Lagar containing the iron chelator ethylenediamine-di(o-hydroxyphenylacetic acid) prior to subculture on blood agar. Intracellular haemolysin was detected in five out of the $\mathbf{2 1}$ strains of $E$. coll grown on L-agar in the atmosphere described above, but haemolysin was not detected in L-broth culture supernatants. The haemolysins lysed guinea pig, mouse and ferret erythrocytes, but not human, rabbit, rat, turkey or chicken erythrocytes. Also, the addition of calcium ions to culture media was not required for haemolytic activity. It was concluded that haemolysins produced by VTEC appear to be quite distinct from $E$. colf $\alpha$-haemolysin and resemble a form of $\beta$-haemolysin.
\end{abstract}

Keywords: Verocytotoxin-producing Escherichia coli, haemolysin, enterohaemolysin, growth conditions, iron

\section{INTRODUCTION}

Haemolysins form a family of lytic toxins which can play a key role in the pathogenesis of disease. Strains of haemolytic Escherichia coli produce either $\alpha$ - or $\beta$ haemolysins which are secreted and cell-associated, respectively. Both types of haemolysin are expressed in the exponential phase of growth, but only $\alpha$-haemolysin requires calcium ions for lytic activity. Recently, strains of Verocytotoxin-producing E. coli (VTEC), belonging to serotypes $\mathrm{O} 26: \mathrm{H} 11, \mathrm{O} 111: \mathrm{H}-$ and $\mathrm{O} 157: \mathrm{H} 7$, were shown to produce a plasmid-encoded haemolysin termed 'enterohaemolysin' (Beutin et al., 1988, 1989, 1994). The extent to which strains of VTEC produce haemolysin has not been elucidated fully; however, a DNA probe (CVD419) devised by Levine et al. (1987) to detect enterohaemorrhagic $E$. coli was used by Schmidt et al. (1995) to detect VTEC producing 'enterohaemolysin'.
The haemolysin described by Schmidt et al. (1995) as enterohaemolysin was shown to be genetically related to E. coli $\alpha$-haemolysin (Schmidt et al., 1995), having a similar molecular mass of approximately $110 \mathrm{kDa}$ and a requirement for calcium ions for haemolytic activity (Beutin et al., 1989). Enterohaemolysin activity has been detected most frequently with washed sheep erythrocytes, but unlike $\alpha$-haemolysin, enterohaemolysin does not lyse horse erythrocytes (Cavalieri et al., 1984; Scotland et al., 1990).

The role of haemolysins in the pathogenesis of VTEC infections is not known. However, patients with haemolytic uraemic syndrome, caused by strains of $E$. coli O157, have been shown to produce serum antibodies to enterohaemolysin (Schmidt et al., 1995), suggesting that this haemolysin is probably expressed during pathogenesis.

With the aim of improving our understanding of the expression of haemolysin by VTEC, we examined strains for production and mode of action of haemolysin. 


\section{METHODS}

Bacteria. All 21 strains of $E$. coli used in the present study (Table 1) were isolated from human cases of diarrhoea, bloody diarrhoea or haemolytic uraemic syndrome. Except for E. coli strain E20513, all strains produced Verocytotoxin VT1, VT2 or both and hybridized with the gene probe CVD419 (Scotland et al., 1990). E. coli strains E92356 and E101402 were $\alpha$-haemolysin-producing control strains. Strains were stored on Dorset's egg agar slopes at room temperature and were obtained from the culture collection held by the Laboratory of Enteric Pathogens (London, UK).

Culture media. Bacteria were grown in L-broth $\left(37^{\circ} \mathrm{C}, 6 \mathrm{~h}\right)$ prior to inoculation of experimental media. One experimental medium used was L-agar (Oxoid) with and without the addition of $\mathrm{CaCl}_{2} \cdot 2 \mathrm{H}_{2} \mathrm{O}(10 \mathrm{mM})$, and with and without $5 \%$ (v/v) erythrocytes from chicken, ferret, guinea pig, human $\left(\mathrm{AB}^{+}, \mathrm{A}^{+}, \mathrm{B}, \mathrm{O}^{+}, \mathrm{O}^{-}\right)$, mouse, rabbit, rat, sheep or turkey. Erythrocytes were washed $(\times 3)$ in PBS $(140 \mathrm{mM} \mathrm{NaCl}$, $2.7 \mathrm{mM} \mathrm{KCl}, 8 \mathrm{mM} \mathrm{Na} \mathrm{HPO}_{4}, 1.5 \mathrm{mM} \mathrm{KH}_{2} \mathrm{PO}_{4}$ ) with and without $10 \mathrm{mM} \mathrm{CaCl} \cdot 2 \mathrm{H}_{2} \mathrm{O}$. Blood agar was also used to make agar plates and agar tubes $(8 \times 1 \mathrm{~cm})$ and bacteria were also grown in L-broth or on L-agar containing $100 \mu \mathrm{g}$ EDDA (Sigma) $\mathrm{ml}^{-1}$, with and without the addition of $5 \mathrm{mM} \mathrm{FeCl}$. EDDA was made iron-free by the method of Rogers (1973). The ability of bacteria to produce gas was determined by growing strains in glucose/peptone broth containing a Durham tube.

Growth conditions. Bacteria were grown in air, in $5 \%$ carbon dioxide in air (British Oxygen) and in atmospheres comprising: (i) $12 \%$ oxygen, $7 \%$ carbon dioxide, $35 \%$ hydrogen and $46 \%$ nitrogen (Oxoid Gas Generating kit BR38 without catalyst); (ii) $8 \%$ carbon dioxide, $40 \%$ hydrogen and $52 \%$ nitrogen (Oxoid Gas Generating kit BR38 without catalyst); (iii) $13 \%$ carbon dioxide and $87 \%$ nitrogen (Oxoid Gas Generating kit BR38); and (iv) $5 \%$ oxygen, $5 \%$ carbon dioxide, $3 \%$ hydrogen and $87 \%$ nitrogen (variable atmosphere incubator; Don Whitley Scientific). Bacteria were grown in these various atmospheres at 37 and $21^{\circ} \mathrm{C}$ for a range of incubation times.

Extracellular/intracellular haemolysin. Strains of E. coli were examined for extracellular haemolysin using L-broth culture supernatants (see below). For the detection of intracellular haemolysin, bacteria were grown on L-agar in an atmosphere of $8 \%$ carbon dioxide, $40 \%$ hydrogen and $52 \%$ nitrogen (Oxoid Gas Generating kit BR38 with catalyst). For agargrown bacteria, the combined cell mass from three plates was harvested. Bacteria were suspended in $5 \mathrm{ml}$ of either PBS alone or PBS containing $1 \%(\mathrm{w} / \mathrm{w})$ BSA (Sigma), prior to sonication (30 s) using a Heat Systems W-225 sonicator (Ultrasonics). Bacterial debris was sedimented by centrifugation $(15000 \mathrm{~g}$,

Table 1. Strains of $E$. coli used in the present study

\begin{tabular}{|c|c|c|c|c|}
\hline Strain no. & Serotype & $\begin{array}{l}\text { Intracellular } \\
\text { haemolysin }\end{array}$ & $\begin{array}{c}\text { Contact } \\
\text { haemolysin } \dagger\end{array}$ & Reference/sourceł \\
\hline E20513\$ & $\mathrm{O} 111: \mathrm{H} 2$ & ND & 0.00 & Chart et al. (1988) \\
\hline E68446 & $\mathrm{O} ?: \mathrm{H}-$ & ND & $7 \cdot 66$ & Thomas et al. (1996) \\
\hline E41787\| & $\mathrm{O} 5: \mathrm{H}-$ & ND & $9 \cdot 33$ & Willshaw et al. (1992) \\
\hline E113378\| & $\mathrm{O} 26: \mathrm{H} 11$ & $2 \cdot 00$ & $41 \cdot 50$ & LEP (unpublished) \\
\hline E105991\| & O26:H11 & 0.86 & $10 \cdot 90$ & LEP (unpublished) \\
\hline E107943\| & $\mathrm{O} 26: \mathrm{H} 11$ & $1 \cdot 50$ & $143 \cdot 59$ & LEP (unpublished) \\
\hline E108848 & $\mathrm{O} 26: \mathrm{H} 11$ & ND & $62 \cdot 18$ & LEP (unpublished) \\
\hline E113372 & $\mathrm{O} 26: \mathrm{H} 11$ & ND & $19 \cdot 77$ & LEP (unpublished) \\
\hline E45037 & $\mathrm{O} 91: \mathrm{H} 21$ & ND & $18 \cdot 02$ & Willshaw et al. (1992) \\
\hline E43549 & O105ac:H19 & ND & $12 \cdot 11$ & Willshaw et al. (1992) \\
\hline E55391 & O111ac:H- & 1.04 & $36 \cdot 44$ & Willshaw et al. (1992) \\
\hline E52849 & O111ac:H- & $1 \cdot 35$ & $17 \cdot 18$ & Willshaw et al. (1992) \\
\hline E75647 & $\mathrm{O} 121: \mathrm{H} 19$ & ND & $30 \cdot 50$ & LEP (unpublished) \\
\hline E113371 & O128ab:H2 & ND & $2 \cdot 51$ & LEP (unpublished) \\
\hline E113375 & O128ab:H2 & ND & $31 \cdot 50$ & LEP (unpublished) \\
\hline E41509 & O128ab:H2 & ND & $110 \cdot 17$ & Willshaw et al. (1992) \\
\hline E40135 & O128ab:H25 & ND & $1 \cdot 84$ & Willshaw et al. (1992) \\
\hline E92568 & $\mathrm{O} 134: \mathrm{H} 25$ & ND & $17 \cdot 51$ & Thomas et al. (1996) \\
\hline $\mathrm{E} 42772$ & $\mathrm{O} 145: \mathrm{H} 25$ & ND & $51 \cdot 40$ & Willshaw et al. (1992) \\
\hline E31708 & $\mathrm{O} 163: \mathrm{H} 19$ & ND & $7 \cdot 67$ & Willshaw et al. (1992) \\
\hline E46091\| & $\mathrm{O} 165: \mathrm{H} 25$ & ND & 32.00 & Willshaw et al. (1992) \\
\hline E80184/1 & $\mathrm{O} 173: \mathrm{H} 2$ & ND & $42 \cdot 41$ & Thomas et al. (1996) \\
\hline
\end{tabular}

* Measured at $430 \mathrm{~nm}$; ND, extracellular haemolysin not detected.

† $\mathrm{OD}_{430}$ /bacterial cell mass.

‡LEP, Laboratory of Enteric Pathogens.

$\$$ Haemolysin-negative control.

\| Strains which did not produce gas. 
$15 \mathrm{~min})$ and supernatants were filtered $(0.45 \mu \mathrm{m}$ filter; Millipore). Culture supernatant or sonicated preparation $(5 \mathrm{ml})$ was mixed with $10 \mu$ l guinea pig blood, washed $(\times 3)$ with PBS and incubated at room temperature for $6 \mathrm{~h}$. Whole erythrocytes were sedimented $(4000 \mathrm{~g}, 5 \mathrm{~min})$ and haemolysis was quantified by measuring the $\mathrm{OD}_{430}$ (Unicam SP600 spectrophotometer; Pye Unicam).

Quantifying intracellular haemolysin. Haemolysin production was quantified by determining the wavelength at which maximum absorbance $\left(\lambda_{\max }\right)$ of lysed guinea pig erythrocytes was observed. Intracellular haemolysin was mixed with guinea pig erythrocytes (as described above) and the $\lambda_{\max }$ for lysed erythrocytes was identified using cell-free supernatant as $430 \mathrm{~nm}$.

Contact haemolysin. Contact haemolysin was detected by the method of Haque et al. (1994), except that calcium ions were omitted from the PBS. Strains of E. coli were grown on L-agar in an atmosphere comprising $8 \%$ carbon dioxide, $40 \%$ hydrogen and $52 \%$ nitrogen at $37^{\circ} \mathrm{C}$ for $16 \mathrm{~h}$, followed by $6 \mathrm{~h}$ in air at $21^{\circ} \mathrm{C}$. Bacterial cell mass was transferred to preweighed screw-capped Eppendorf tubes and reacted with guinea pig erythrocytes.

Oxygen scavengers. Guinea pig blood agar plates and tubes were prepared containing: $5 \%(\mathrm{v} / \mathrm{v})$ DMSO; $5 \mathrm{mM}$ sodium hydrosulphite; $5 \mathrm{mM}$ 1,3-diphenylisofuran; or $5 \mathrm{mM}$ DTT (all from Sigma).

\section{RESULTS}

\section{Haemolysin production}

Strains of E. coli 'streaked' onto the surface of L-agar containing washed (PBS/ $\mathrm{CaCl}_{2}$ ) sheep erythrocytes produced zones of haemolysis which extended approximately $1 \mathrm{~mm}$ beyond the edge of the bacterial cell mass but not around individual colonies. However, when bacteria were inoculated into blood agar with a straight wire the zones of haemolysis were noticeably larger, although zones around individual colonies were very narrow. In contrast, control strains of $\alpha$-haemolysinproducing E. coli gave clear zones of haemolysis under these growth conditions.

Inoculating bacteria deep into sheep blood agar tubes with a straight wire resulted in complete clearing of the blood agar down to the point reached by the inoculating wire. For 16 strains, the agar tubes became fragmented due to production of gas (Table 1); these strains were subsequently shown to produce gas when growing in glucose/peptone broth with an inverted Durham tube. E. coli strains E41787, E46091, E113378, E105991 and E107943 were non-gas producing and were used for further studies.

\section{Role of calcium in haemolysis}

The role of calcium ions in the haemolytic process was examined using the blood agar tube method. Washing sheep erythrocytes $(\times 3)$ in PBS was essential for haemolysis; however, the addition of $\mathrm{CaCl}_{2}$ to either erythrocyte washing solutions or blood agar was not required for haemolytic activity. In contrast, the $\alpha$ haemolysin-producing control strains required sheep

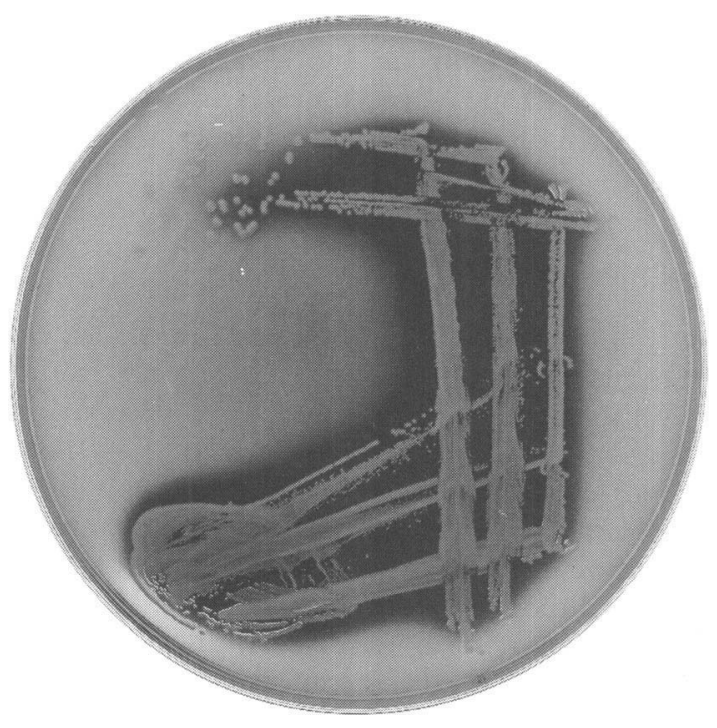

Fig. 1. Strains of $E$. coli were most haemolytic when grown in an atmosphere comprising $8 \%$ carbon dioxide, $40 \%$ hydrogen and $52 \%$ nitrogen at $37^{\circ} \mathrm{C}$ for $16 \mathrm{~h}$, followed by $6 \mathrm{~h}$ in air at $21^{\circ} \mathrm{C}$.

cells to be washed with $\mathrm{PBS} / \mathrm{CaCl}_{2}$ for haemolysis to occur.

\section{Haemolysin specificity}

Using blood agar tubes, strains of $E$. coli lysed guinea pig, mouse and ferret erythrocytes from, but not those from human, rabbit, rat, turkey or chicken.

\section{Oxygen scavengers}

The role of oxygen in haemolysin production was examined by growing strains in the presence of oxygen scavengers. Addition of DMSO, sodium hydrosulphite, 1,3-diphenylisofuran or DTT to blood agar did not influence haemolysin production.

\section{Growth atmosphere}

Strains of E. coli produced maximum zones of haemolysis when grown on L-agar plates containing guinea pig erythrocytes in an atmosphere comprising $8 \%$ carbon dioxide, $40 \%$ hydrogen and $52 \%$ nitrogen at $37^{\circ} \mathrm{C}$ for $16 \mathrm{~h}$, followed by $6 \mathrm{~h}$ in air at $21^{\circ} \mathrm{C}$ (Fig. 1). Haemolysin production was reduced if the $6 \mathrm{~h}$ incubation period was carried out at either $37^{\circ} \mathrm{C}$ in air or $21{ }^{\circ} \mathrm{C}$ in $8 \%$ carbon dioxide, $40 \%$ hydrogen and $52 \%$ nitrogen.

\section{Iron and haemolysin production}

Bacteria grown on L-agar containing EDDA were used to inoculate L-agar plates containing $5 \%$ guinea pig erythrocytes prior to culture in an atmosphere comprising $8 \%$ carbon dioxide, $40 \%$ hydrogen and $52 \%$ 
nitrogen at $37^{\circ} \mathrm{C}$ for $16 \mathrm{~h}$, followed by $6 \mathrm{~h}$ in air at $21^{\circ} \mathrm{C}$. Bacteria grown on blood agar produced noticeably larger zones of haemolysis compared with bacteria grown on L-agar containing EDDA with added $\mathrm{FeCl}_{3}$.

\section{Extracellular/intracellular haemolysin}

Haemolysin activity was not detected in broth culture supernatants prepared from any of the strains examined. However, intracellular haemolysin was detected in five of the 21 test strains when bacteria were grown on agar and sonicated (Table 1). For the detection of intracellular haemolysin, it was essential to grow strains on $\mathrm{L}$-agar plates incubated in an atmosphere comprising $8 \%$ carbon dioxide, $40 \%$ hydrogen and $52 \%$ nitrogen; haemolysin activity was detected only when BSA was present in the PBS used for sonication. Extracellular $\alpha$ haemolysin was detected with control strains of $E$. coli.

\section{DISCUSSION}

The production of haemolysins by strains of VTEC was influenced considerably by environmental growth conditions. The maximum observed haemolysin production was achieved by growing bacteria in agar tubes, suggesting that either component gases in air were inhibiting haemolysin production or the gas mixture generated by bacteria growing deep in agar columns was particularly suitable for the expression of haemolysin. With blood agar plates, maximum observed haemolysin activity was detected with an atmosphere comprising $8 \%$ carbon dioxide, $40 \%$ hydrogen and $52 \%$ nitrogen, suggesting that a component of air was inhibiting haemolysin production. However, the use of oxygen scavengers showed that oxygen did not inhibit haemolysin production, suggesting that expression of the haemolysin may have been influenced by the specific ratio of carbon dioxide: hydrogen: nitrogen.

Maximum observed haemolysin production was detected when bacteria were grown in a specific atmosphere at $37^{\circ} \mathrm{C}$ for $16 \mathrm{~h}$, followed by $6 \mathrm{~h}$ in air at $21^{\circ} \mathrm{C}$. The reasons why this temperature regime should increase haemolysin production are unknown; however, other workers (Beutin et al., 1995) have also employed a two-step incubation temperature of $37^{\circ} \mathrm{C}$ followed by $30^{\circ} \mathrm{C}$ to maximize haemolysin production. It would seem unlikely that a two-step temperature regime was essential for the expression of haemolysin during pathogenesis.

The observation that haemolysin was not detected in broth culture supernatants but could be detected intracellularly suggested that haemolysin was made but not exported from the cell. This resembles the situation in strains of Edwardsiella tarda which are haemolytic although haemolysin cannot be detected in culture supernatants (Janda \& Abbott, 1993).

The haemolytic action of haemolysin did not require the addition of calcium ions, which are essential for $\alpha$ - haemolysin activity (Beutin, 1991). This suggests that either the culture media contain sufficient calcium for haemolysis to take place or the observed haemolysis was calcium-independent. Calcium-independent haemolysins have been described for bacteria such as Proteus spp. and Serratia marcescens (Welch, 1987; Koronakis et al., 1987; Braun et al., 1985). It is possible that the haemolysin described herein may belong to the calciumindependent family of haemolysins and therefore be quite distinct from $\alpha$-haemolysin.

Growing strains of VTEC on iron-restricted L-agar, prior to inoculation of blood agar plates, increased haemolysin production, suggesting that this haemolysin was iron-regulated. Certain haemolysins, including $\alpha$ haemolysin, are iron-regulated with the expression of toxin controlled by the chromosomally located fur gene (Grunig et al., 1987). Haemolysis during pathogenesis has been postulated as a means of providing pathogenic bacteria with iron (Lebek \& Gruening, 1985); the ironrestricted conditions existing in host tissues may form the switch for the expression of haemolysin. A feature of human infections with VTEC, particularly with $E$. coli O157:H7, is haemolytic anaemia, which may be caused by a haemolysin. However, since our studies showed that haemolysin did not lyse human erythrocytes, its role in the pathogenesis of VTEC infections remains to be resolved. Beutin et al. (1989) described an $\alpha$-like haemolysin, termed enterohaemolysin, which lysed human erythrocytes; we failed to observe this with our panel of VTEC using human erythrocytes belonging to a range of blood groups. We conclude that VTEC haemolysins are unlike E. coli $\alpha$-haemolysin in not being actively secreted and not requiring calcium ions for activity.

\section{ACKNOWLEDGEMENTS}

This study was funded in part by a grant from the Department of Health.

\section{REFERENCES}

Beutin, L. (1991). The different hemolysins of Escherichia coli. Med Microbiol Immunol 180, 167-182.

Beutin, L., Prada, J., Zimmerman, S., Stephan, R., Ørskov, I. \& Ørskov, F. (1988). Haemolysin, a new type of haemolysin produced by some strains of enteropathogenic $E$. coli (EPEC). Zentralbl Bakteriol Mikrobiol Hyg Abt 267, 576-588.

Beutin, L., Montenegro, M. A., Ørskov, I., Ørskov, F., Prada, J., Zimmerman, S. \& Stephan, R. (1989). Close association of Verotoxin (Shiga-like toxin) production with haemolysin production in strains of Escherichia coli. J Clin Microbiol 27, 2559-2564.

Beutin, L., Alexksic, S., Zimmerman, S. \& Gleier, K. (1994). Virulence factors and phenotypic traits of Verotoxigenic strains of $E s$ cherichia coli isolated from human patients in Germany. Med Microbiol Immunol 183, 13-21.

Beutin, L., Geier, D., Zimmerman, S. \& Karch, H. (1995). Virulence markers of Shiga-like toxin-producing Escherichia coli strains originating from healthy domestic animals of different species. J Clin Microbiol 33, 631-635. 
Braun, V., Gunther, H., Neuss, B. \& Tautz, C. (1985). Hemolytic activity of Serratia marcescens. Arch Microbiol 141, 371-376.

Cavalieri, S. J., Bohach, G. A. \& Snyder, I. R. (1984). Escherichia coli $\alpha$-haemolysin: characteristics and probable role in pathogenicity. Microbiol Rev 48, 326-343.

Chart, H., Scotland, S. M., Willshaw, G. A. \& Rowe, B. (1988). HEp-2 adhesion and expression of a $94 \mathrm{kDa}$ outer-membrane protein by strains of Escherichia coli belonging to enteropathogenic serogroups. J Gen Microbiol 134, 1315-1321.

Grunig, H.-M., Rutschi, D., Schooch, C. \& Lebek, G. (1987). The chromosomal fur gene regulates the extracellular haemolytic activity encoded by certain hly plasmids. Zentralbl Bakteriol Mikrobiol Hyg Abt 266, 231-238.

Haque, M. A., Ohki, K., Kikuchi, M. \& Kohashi, O. (1994). Contact haemolysin production by strains of enteroaggregative Escherichia coli isolated from children with diarrhea. J Clin Microbiol 32, 1109-1111.

Janda, J. M. \& Abbott, S. L. (1993). Expression of an iron-regulated hemolysin by Edwardsiella tarda. FEMS Microbiol Lett 111, 275-280.

Koronakis, V., Cross, M., Senior, B., Koronakis, E. \& Hughes, C. (1987). The secreted hemolysins of Proteus morganii, Proteus vulgaris and Morganella morganii are genetically related to each other and the alpha hemolysin of Escherichia coli. J Bacteriol 169, 1509-1515.

Lebek, G. \& Gruening, H. M. (1985). Relationship between the hemolytic property and iron metabolism in Escherichia coli. Infect Immun 50, 682-686.
Levine, M. M., Xu, J-G., Kaper, J. B., Lior, H., Prado, V., Tall, B., Nataro, J., Karch, H. \& Wachsmuth, K. (1987). A DNA probe to identify enterohemorrhagic Escherichia coli of 0157:H7 and other serotypes that cause hemorrhagic colitis and hemolytic uremic syndrome. J Infect Dis 156, 175-182.

Rogers, H. J. (1973). Iron-binding catechols and virulence in Escherichia coli. Infect Immun 7, 445-456.

Schmidt, H., Beutin, L. \& Karch, H. (1995). Molecular analysis of the plasmid-encoded hemolysin of Escherichia coli 0157:H7 strain EDL 933. Infect Immun 63, 1055-1061.

Scotland, S. M., Willshaw, G. A., Smith, H. R. \& Rowe, B. (1990). Properties of strains of Escherichia coli O26:H11 in relation to their enteropathogenic or enterohemorrhagic classification. $J$ Infect Dis 162, 1069-1074.

Thomas, A., Cheasty, T., Frost, J. A., Chart, H., Smith, H. R. \& Rowe, B. (1996). Verocytotoxin-producing Escherichia coli, particularly serogroup O157, associated with human infections in England and Wales: 1992-4. Epidemiol Infect 117, 1-10.

Welch, R. A. (1987). Identification of two different hemolysin determinants in uropathogenic Proteus isolates. Infect Immun 55, 2183-2190.

Willshaw, G. A., Scotland, S. M., Smith, H. R. \& Rowe, B. (1992). Properties of Verocytotoxin-producing Escherichia coli of human origin of $\mathrm{O}$ serogroups other than O157. I Infect Dis 166, 797-802.

Received 4 July 1997; revised 25 August 1997; accepted 2 September 1997. 